\title{
Follicular Dendritic Cell Sarcoma of Parapharyngeal Space: A Case Report and Review of the Literature
}

\author{
Turki Al-Hussain • Muhammad Saleem • \\ Suresh Babu Velagapudi • Mohammad Anas Dababo
}

Received: 5 December 2013/Accepted: 19 March 2014/Published online: 26 March 2014

(C) Springer Science+Business Media New York 2014

\begin{abstract}
Follicular dendritic cell sarcoma (FDCS) of the parapharyngeal space is a rare malignant tumor. Only eleven cases of FDCS of the parapharyngeal space have been reported in English literature. Most of the reported cases developed tumor recurrence within 1 year or had metastasis. Because of the rarity of FDCS in the parapharyngeal space and peculiar histology, it can be misdiagnosed as undifferentiated carcinoma or meningioma. Therefore, pathologists should be aware of the existence of FDCS in this location. This paper aims to report a unique case of FDCS of the parapharyngeal space without recurrence in 26 months follow up with a review of the literature.
\end{abstract}

Keywords Follicular dendritic cell sarcoma · FDCS . Extranodal · Parapharyngeal space

\section{Introduction}

Follicular dendritic cell sarcoma (FDCS) is a rare malignant neoplasm arising from follicular dendritic cells of the lymphoid follicles at nodal or extranodal sites. It

T. Al-Hussain $(\bowtie) \cdot$ M. A. Dababo

Department of Pathology and Laboratory Medicine, King Faisal Specialist Hospital and Research Centre, Riyadh, Saudi Arabia e-mail: turkihussain@kfshrc.edu.sa

M. Saleem · S. B. Velagapudi

Department of Otolaryngology, Head and Neck Surgery, King Faisal Specialist Hospital and Research Centre, Riyadh, Saudi Arabia was first described in 1986 by Monda et al. [1] in a series of four cases involving lymph nodes. Following initial description, only a few reports of nodal and extranodal FDCS have been published. Extranodal FDCS was first described in 1994 by Chan et al. [2] who reported follicular dendritic cell tumors of the oral cavity, one in the soft palate and one in the tonsil. The most common extranodal sites are tonsil, nasopharynx, palate, stomach, small and large bowel, pancreas, liver, neck soft tissue, and intraabdominal. Other extranodal sites include the parapharyngeal space where only eleven cases have been reported in the English literature. FDCS can be misdiagnosed as undifferentiated carcinoma [3]. Therefore, pathologists should be aware of the existence of FDCS in the parapharyngeal space to avoid misdiagnosis. Herein, we report a unique case of FDCS of the parapharyngeal space without recurrence in 26 months follow up with a review of the previously reported cases in that location.

\section{Case Report}

A 22-year-old man presented with a lump in the left parapharyngeal region for 8 months duration. There was no history of dysphagia or constitutional symptoms. Physical examination showed left sided parapharyngeal, non-tender firm swelling. Cervical lymph nodes were not palpable.

Computed tomography (CT) scan showed left parapharyngeal mass causing some obliteration of the left parapharyngeal fat space with displacement of the left internal and external jugular veins to the lateral side (Fig. 1a). On magnetic resonance imaging study, the mass was 

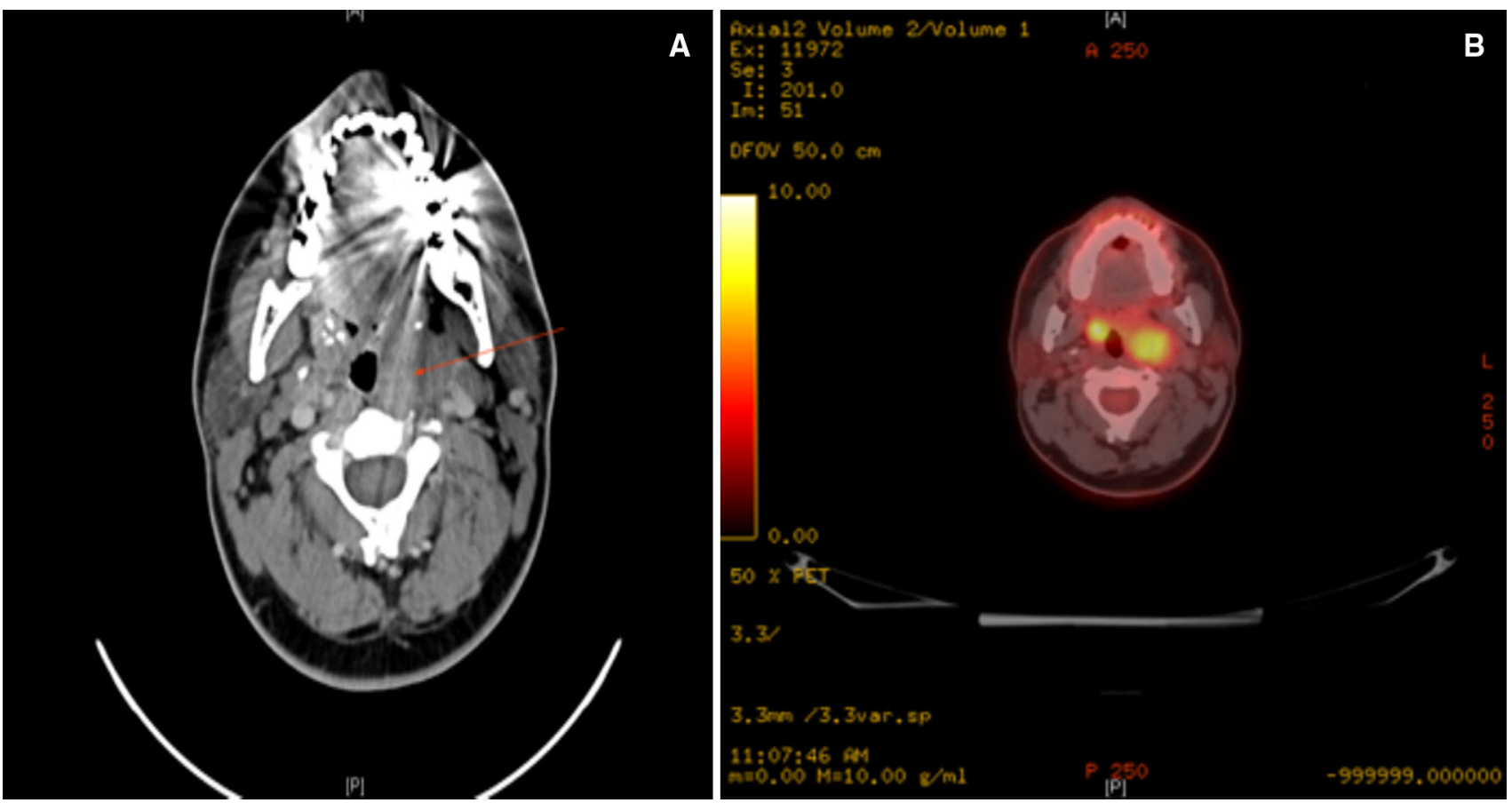

Fig. 1 a Preoperative computed tomography (CT) scan. b FDG PET scan

enhancing and measuring approximately $4.0 \times 3.0 \times 1.5 \mathrm{~cm}$. Few enlarged cervical lymph nodes were identified. FDG PET whole body scan showed that this tumor had avid uptake locally with no other uptake in the body (Fig. 1b). The patient underwent surgical biopsy.

Macroscopically, the mass was composed of multiple white tan firm fragments measuring in aggregates $2.0 \times 1.0 \times 0.3 \mathrm{~cm}$. Microscopically, the tumor was composed of spindled to ovoid cells with variable cellularity and vague nodularity (Fig. 2a, b). The neoplastic cells formed fascicles and focally showed whorls reminiscent of meningioma (Fig. 2c). Lymphocytic infiltrate was present among neoplastic cells (Fig. 2c). The neoplastic cells had eosinophilic cytoplasm with indistinct cell borders and oval to somewhat pleomorphic nuclei including multinucleated cells (Fig. 2a, b). The nuclei were vesicular with distinct, occasionally prominent, nucleoli and thin nuclear membrane.
Few nuclear pseudoinclusions were also identified (Fig. 2d).

Immunohistochemical studies were performed using anti-CD23 (Ventana; pre diluted), anti-CD21 (Ventana; pre diluted), anti-CD35 (Novocastra; dilution 1:50), antiS-100 protein (Ventana; pre diluted), anti-cytokeratin AE1/AE3 (Ventana; pre diluted), and anti-Ki-67 (Ventana; pre diluted). The tumor cells were strongly positive for CD23, CD21, and CD35 (Fig. 3a-c) while negative for S-100 protein and cytokeratin AE1/AE3. Ki-67 proliferation index was less than $10 \%$. Also, in situ hybridization for Epstein-Barr virus, EBER (Novocastra; pre diluted) was performed and showed negative signals. These results confirmed our diagnosis of FDCS and ruled out other differential diagnoses such as carcinoma and meningioma.

The patient underwent a second surgical excision followed by radiotherapy; 70 cGy radiation as external beam. The tumor showed good response to radiotherapy with 

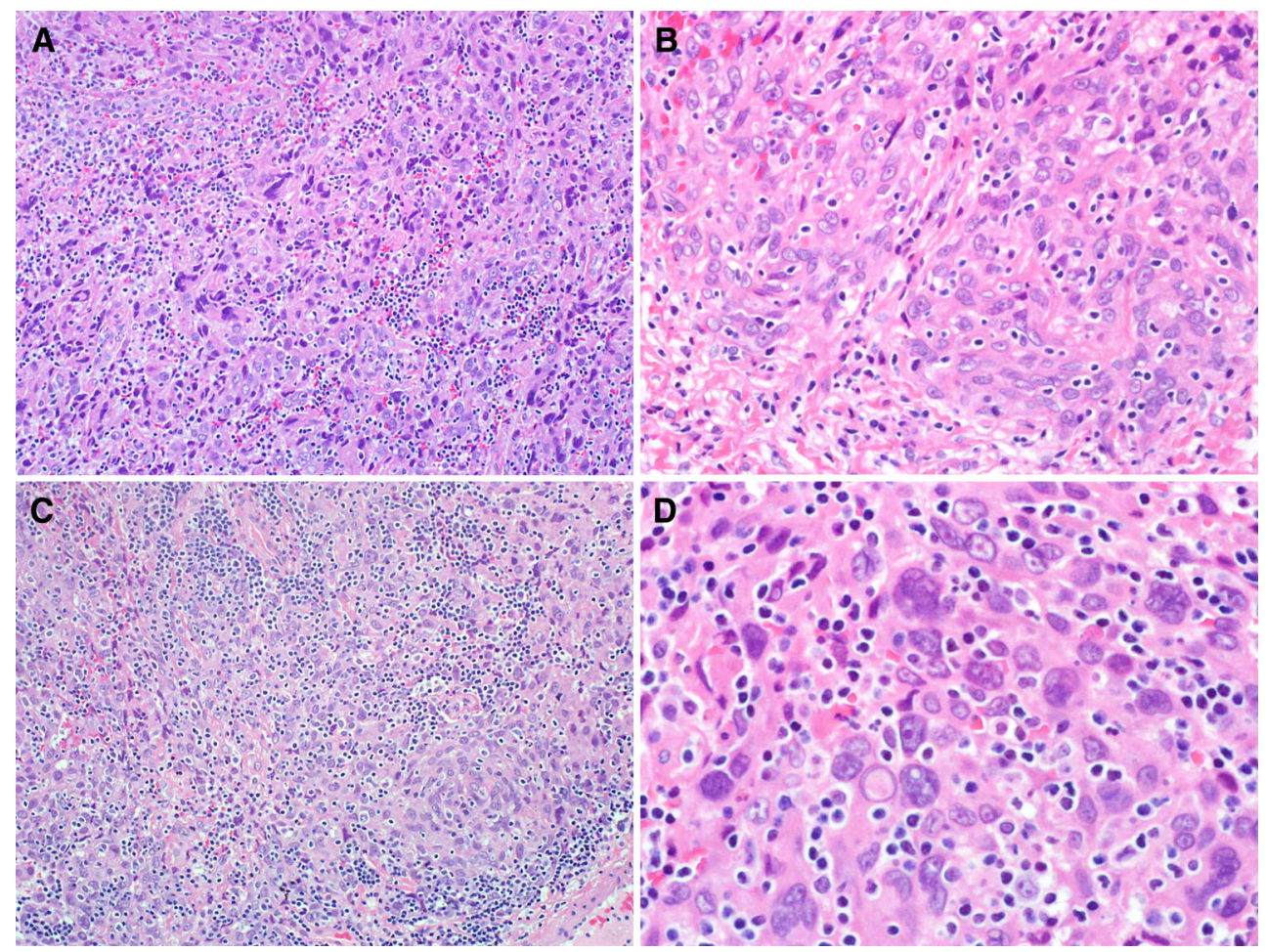

Fig. 2 a FDCS with variable cellularity and pleomorphic cells (H\&E, $\times 200$ ). b Ovoid to spindled cells with indistinct cell borders and eosinophilic cytoplasm $(\mathrm{H} \& \mathrm{E}, \times 400)$. c Many small lymphocytes

complete regression. There is no evidence of recurrence at 26 months of follow up or metastasis.

\section{Discussion}

Follicular dendritic cell sarcoma is a rare malignant neoplasm that involves nodal and extranodal sites. Nodal FDCS comprises one half to two-thirds of cases with the cervical lymph nodes being the most often affected site [4]. Extranodal FDCS can involve different sites, such as the tonsil, oral cavity, stomach, intestines, soft tissue, mediastinum, liver, spleen and peritoneum. FDCS of the parapharyngeal space is one of the rarely involved regions. Only eleven cases of FDCS of the parapharyngeal space have been reported in the English literature [2, 5-12]. Most of the published cases of FDCS were initially misdiagnosed as meningioma, paraganglioma, or undifferentiated carcinoma particu- among neoplastic cells with focal whirling simulating meningioma $(H \& E, \times 200)$. d Nuclear pseudoinclusion and some cells with prominent nucleoli $(\mathrm{H} \& \mathrm{E}, \times 600)$

larly if it involved unusual sites such as the parapharyngeal space. This is most likely because FDCS rarely involves parapharyngeal space, hence pathologists may not include FDCS in the differential diagnosis of parapharyngeal space tumors. However, when suspected based on morphology, the diagnosis can be relatively straight forward especially with support of immunohistochemical stains.

Few cases of FDCS have been associated with paraneoplastic pemphigus and hyaline vascular type Castleman disease [13, 14]. FDCS is most often present as a painless slow growing mass, with median size of $5.0 \mathrm{~cm}$ [4]. Microscopically, the tumor was composed of spindled to ovoid cells arranged in fascicles, storiform patterns, whorls, diffuse sheets or vague nodules. The cells have a moderate amount of eosinophilic cytoplasm with indistinct cell borders and the nuclei are oval or elongated with vesicular or granular chromatin and small distinct nucleoli. Nuclear pseudoinclusion, binucleation and multinucleation may be seen. The 


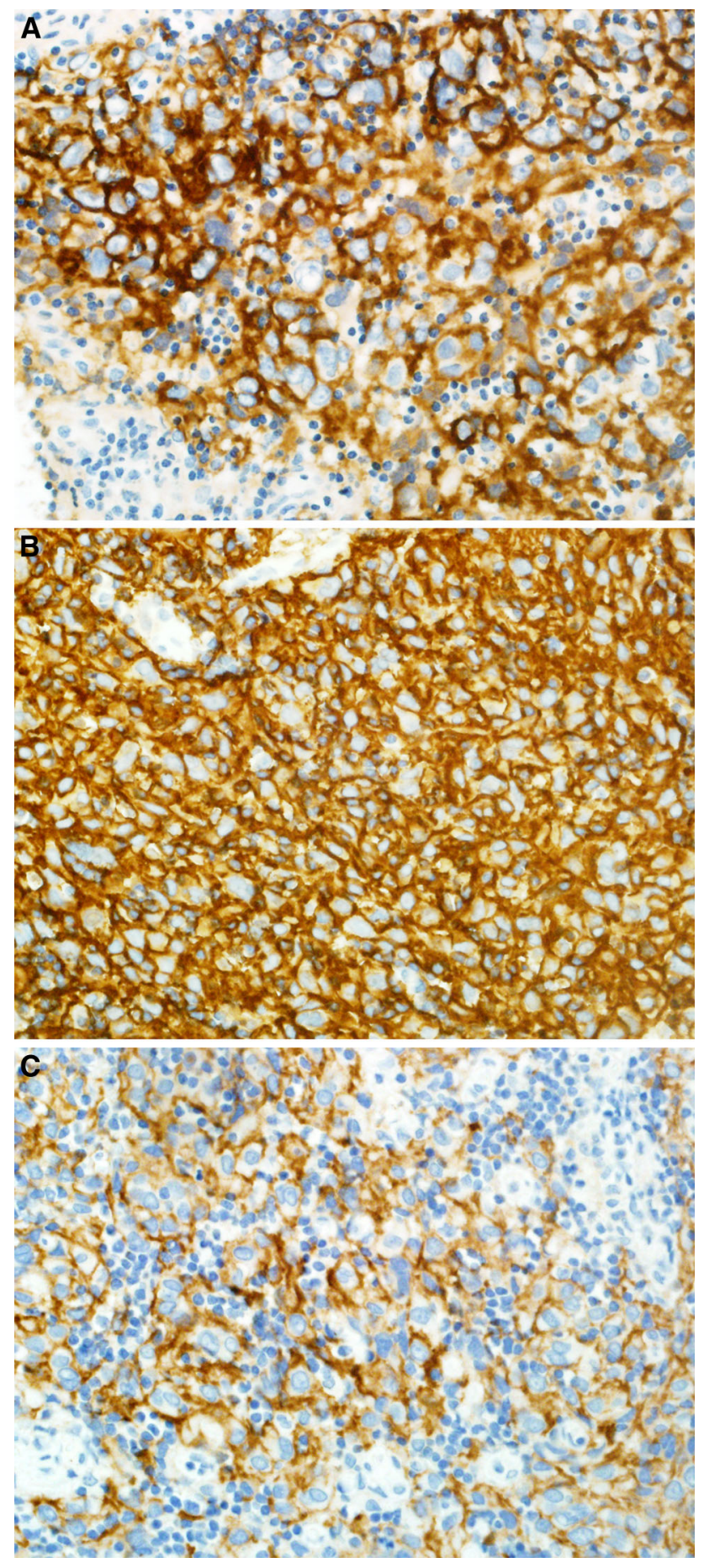

Fig. 3 a Positive immunoreactivity against CD21 $(\times 400)$. b Positive immunoreactivity against CD23 $(\times 200)$. c Positive immunoreactivity against CD35 $(\times 200)$ tumor usually exhibits mild to moderate nuclear atypia and mitotic rate ranges from 0 to 50 per 10 high power fields [4]. Marked nuclear atypia and necrosis have been reported. Immunohistochemical stains are important to confirm the diagnosis. FDCS is positive for follicular dendritic cell markers such as CD21, CD35 and CD23. It is also positive for clusterin, vimentin and fascin. EBER signals were demonstrated in some FDCS [15-17].

Follicular dendritic cell sarcoma has indolent behavior. Chen et al. [2] suggested that FDCS should be considered at least of intermediate grade where they studied 17 cases of FDCS and found that the overall recurrence, metastasis, and mortality rates were 43,24 , and $17 \%$; respectively. Dominguez-Malagon et al. [8] suggested that extranodal FDCS of the pharyngeal region behaves as a low-grade sarcoma. Li et al. [10] suggested histological criteria for low- and high-grade FDCS using six parameters which included architectures (nodular vs. diffuse), cellular features (spindle with mild nuclear atypia vs. epithelioid with marked nuclear atypia), mitotic counts ( $<5$ vs. $\geq 5 / 10$ HPF), Ki-67 ( $<10$ vs. $\geq 10 \%$ ), necrosis (absent vs. frequently present), and lymphocyte infiltration (sporadic vs. focal). They also proposed a model for recurrence risk assessment based on tumor size $(<5$ vs. $\geq 5 \mathrm{~cm})$ and histologic grade. FDCS were classified into low-, intermediate-, and high-risk groups and the recurrence rates in these groups were 16,46 , and $73 \%$, and the mortality rates were 0,4 , and $45 \%$, respectively. Applying this proposed system, our current case would be low grade and in the lowrisk group which might explain the longer disease free survival.

The previously reported eleven cases of FDCS of the parapharyngeal space with the current case are summarized in Table 1. In comparison to our case, which had 26 months follow up without recurrence or metastasis, most of the reported cases developed tumor recurrence within 1 year or had metastasis. Only one patient reported by Satoh et al. [7] had no evidence of disease in 2 years. In conclusion FDCS of the parapharyngeal space is a very rare tumor with indolent behavior. It can be easily misdiagnosed as undifferentiated carcinoma or meningioma. Therefore, FDCS should be considered in the differential diagnosis of this location especially by pathologist to avoid misdiagnosis. 
Table 1 Summary of 11 cases of extranodal FDCS of the parapharyngeal region that have previously been reported in the literature and the current case

\begin{tabular}{|c|c|c|c|c|c|}
\hline References & $\begin{array}{l}\text { Sex/ } \\
\text { age } \\
\text { (year) }\end{array}$ & Size $(\mathrm{cm})$ & Initial diagnosis & Treatment & Follow-up \\
\hline Chan et al. [2] & $\mathrm{F} / 40$ & $7 \times 3 \times 2$ & NA & Surgery & Local recurrence at $12 \mathrm{~m}$ \\
\hline Desai et al. [5] & $\mathrm{F} / 45$ & $6 \times 3 \times 3$ & Ectopic meningioma & Surgery and radiotherapy & Local recurrence at $30 \mathrm{~m}$ \\
\hline $\begin{array}{l}\text { Vargas } \\
\text { et al. [6] }\end{array}$ & $\mathrm{F} / 54$ & 6 & FDC tumor & $\begin{array}{l}\text { Surgery, radiotherapy and } \\
\text { chemotherapy }\end{array}$ & Recurrence at $8 \mathrm{~m}$ \\
\hline Satoh et al. [7] & $\mathrm{M} / 16$ & $3 \times 2.5$ & Low-grade malignant tumor & $\begin{array}{l}\text { Surgery, radiotherapy and } \\
\text { chemotherapy }\end{array}$ & $\mathrm{NED}, 24 \mathrm{~m}$ \\
\hline \multirow[t]{2}{*}{$\begin{array}{l}\text { Dominguez- } \\
\text { Malagon } \\
\text { et al. [8] }\end{array}$} & $\mathrm{F} / 29$ & 4.8 & Malignant meningioma & Surgery and radiotherapy & $\begin{array}{l}\text { Recurrence at } 12 \mathrm{~m} \text { with cervical } \\
\text { lymph node metastasis, DOD, } \\
10 \text { years }\end{array}$ \\
\hline & $\mathrm{M} / 26$ & NA & FDC sarcoma & $\begin{array}{l}\text { Surgery, radiotherapy and } \\
\text { chemotherapy }\end{array}$ & Lung metastasis at $36 \mathrm{~m}$ \\
\hline $\begin{array}{l}\text { Alexander } \\
\text { et al. [9] }\end{array}$ & $\mathrm{M} / 69$ & 3 & Paraganglioma & Surgery & Recurrence at $12 \mathrm{~m}$ \\
\hline \multirow[t]{2}{*}{ Li et al. [10] } & $\mathrm{F} / 35$ & 5 & Nasopharyngeal carcinoma & Surgery & $\begin{array}{l}\text { Local recurrence at } 2 \mathrm{~m}, \mathrm{DOD} \text {, } \\
12 \mathrm{~m}\end{array}$ \\
\hline & $\mathrm{F} / 28$ & 6 & FDC sarcoma & $\begin{array}{l}\text { Surgery, radiotherapy and } \\
\text { chemotherapy }\end{array}$ & $\begin{array}{l}\text { Lung metastasis at } 14 \mathrm{~m}, \mathrm{AWD} \text {, } \\
22 \mathrm{~m}\end{array}$ \\
\hline Pyo et al. [11] & $\mathrm{M} / 31$ & $4.7 \times 4.5 \times 1.9$ & $\begin{array}{l}\text { Spindle cell neoplasm } \\
\text { including paraganglioma } \\
\text { (on cytology) }\end{array}$ & Surgery and radiotherapy & NA \\
\hline Hu et al. [12] & $\mathrm{F} / 64$ & $6 \times 4 \times 3$ & Squamous cell carcinoma & Surgery and chemotherapy & $\mathrm{DOD}, 7 \mathrm{~m}$ \\
\hline Current case & $\mathrm{M} / 22$ & $4 \times 3 \times 1.5$ & FDC sarcoma & Surgery and radiotherapy & $\mathrm{NED}, 26 \mathrm{~m}$ \\
\hline
\end{tabular}

$N A$ not available, $N E D$ no evidence of disease, $D O D$ died of disease, $A W D$ alive with disease, $m$ months

\section{References}

1. Monda L, Warnke R, Rosai J. A primary lymph node malignancy with features suggestive of dendritic reticulum cell differentiation. A report of 4 cases. Am J Pathol. 1986;122:562-72.

2. Chan JK, Tsang WY, Ng CS, Tang SK, Yu HC, Lee AW. Follicular dendritic cell tumors of the oral cavity. Am J Surg Pathol. 1994;18:148-57.

3. Duan GJ, Wu F, Zhu J, Guo DY, Zhang R, et al. Extranodal follicular dendritic cell sarcoma of the pharyngeal region. Am J Clin Pathol. 2010;133:49-58.

4. Swerdlow SH, Campo E, Harris NL, Jaffe ES, et al. WHO classification of tumors of haematopoietic and lymphoid tissues. 4th ed. Lyon: International Agency for Research on Cancer; 2008.

5. Desai S, Deshpande RB, Jambhekar N. Follicular dendritic cell tumor of the parapharyngeal region. Head Neck. 1999;21:164-7.

6. Vargas H, Mouzakes J, Purdy SS, Cohn AS, et al. Follicular dendritic cell tumor: an aggressive head and neck tumor. Am J Otolaryngol. 2002;23:93-8.

7. Satoh K, Hibi G, Yamamoto Y, Urano M, et al. Follicular dendritic cell tumor in the oro-pharyngeal region: report of a case and a review of the literature. Oral Oncol. 2003;39:415-9.

8. Domínguez-Malagón H, Cano-Valdez AM, Mosqueda-Taylor A, Hes O. Follicular dendritic cell sarcoma of the pharyngeal region: histologic, cytologic, immunohistochemical, and ultrastructural study of three cases. Ann Diagn Pathol. 2004;8:325-32.

9. Alexander AA, Zapanta PE, Khan A. Diagnosis and recurrence of follicular dendritic cell sarcoma. Otolaryngol Head Neck Surg. 2007;137:832-4.
10. Li L, Shi YH, Guo ZJ, Qiu T, Guo L, Yang HY, Zhang X, Zhao $\mathrm{XM}, \mathrm{Su} \mathrm{Q}$. Clinicopathological features and prognosis assessment of extranodal follicular dendritic cell sarcoma. World $\mathrm{J}$ Gastroenterol. 2010;28(16):2504-19.

11. Pyo JS, Kang G, Do SI, Chae SW, et al. Extranodal follicular dendritic cell sarcoma with rapid growth in parapharynx: a case report. Korean J Pathol. 2012;46:306-10.

12. Hu T, Wang X, Yu C, Yan J, Zhang X, Li L, Li X, Zhang L, Wu J, Ma W, Li W, Wang G, Zhao W, Gao X, Zhang D, Zhang M. Follicular dendritic cell sarcoma of the pharyngeal region. Oncol Lett. 2013;5:1467-76.

13. Katano H, Kaneko K, Shimizu S, Saito T, et al. Follicular dendritic cell sarcoma complicated by hyaline-vascular type Castleman's disease in a schizophrenic patient. Pathol Int. 1997;47: $703-6$.

14. Lee IJ, Kim SC, Kim HS, Bang D, et al. Paraneoplastic pemphigus associated with follicular dendritic cell sarcoma arising from Castleman's tumor. J Am Acad Dermatol. 1999;40:294-7.

15. Cheuk W, Chan JK, Shek TW, Chang JH, Tsou MH, Yuen NW, $\mathrm{Ng}$ WF, Chan AC, Prat J. Inflammatory pseudotumor-like follicular dendritic cell tumor: a distinctive low-grade malignant intra-abdominal neoplasm with consistent Epstein-Barr virus association. Am J Surg Pathol. 2001;25:721-31.

16. Chen TC, Kuo TT, Ng KF. Follicular dendritic cell tumor of the liver: a clinicopathologic and Epstein-Barr virus study of two cases. Mod Pathol. 2001;14:354-60.

17. Bai LY, Kwang WK, Chiang IP, Chen PM. Follicular dendritic cell tumor of the liver associated with Epstein-Barr virus. Jpn J Clin Oncol. 2006;36:249-53. 